\title{
A Review of the Sustainability Concept and the State of SDG Monitoring Using Remote Sensing
}

\author{
Ronald C. Estoque 1
}

National Institute for Environmental Studies, Tsukuba, Ibaraki 305-8506, Japan; estoque.ronaldcanero@nies.go.jp or rons2k@yahoo.co.uk

Received: 4 April 2020; Accepted: 11 May 2020; Published: 31 May 2020

check for updates

\begin{abstract}
The formulation of the 17 sustainable development goals (SDGs) was a major leap forward in humankind's quest for a sustainable future, which likely began in the 17th century, when declining forest resources in Europe led to proposals for the re-establishment and conservation of forests, a strategy that embodies the great idea that the current generation bears responsibility for future generations. Global progress toward SDG fulfillment is monitored by 231 unique social-ecological indicators spread across 169 targets, and remote sensing (RS) provides Earth observation data, directly or indirectly, for $30(18 \%)$ of these indicators. Unfortunately, the UN Global Sustainable Development Report 2019-The Future is Now: Science for Achieving Sustainable Development concluded that, despite initial efforts, the world is not yet on track for achieving most of the SDG targets. Meanwhile, through the EO4SDG initiative by the Group on Earth Observations, the full potential of RS for SDG monitoring is now being explored at a global scale. As of April 2020, preliminary statistical data were available for $21(70 \%)$ of the 30 RS-based SDG indicators, according to the Global SDG Indicators Database. Ten (33\%) of the RS-based SDG indicators have also been included in the SDG Index and Dashboards found in the Sustainable Development Report 2019-Transformations to Achieve the Sustainable Development Goals. These statistics, however, do not necessarily reflect the actual status and availability of raw and processed geospatial data for the RS-based indicators, which remains an important issue. Nevertheless, various initiatives have been started to address the need for open access data. RS data can also help in the development of other potentially relevant complementary indicators or sub-indicators. By doing so, they can help meet one of the current challenges of SDG monitoring, which is how best to operationalize the SDG indicators.
\end{abstract}

Keywords: sustainable development; Earth observation; SDG indicators; EO4SDG; SDG global indicator framework; global SDG indicators database; social-ecological indicators

\section{Introduction}

In the report "Our Common Future" (also known as the Brundtland Report), the World Commission on Environment and Development has defined sustainable development as "development that meets the needs of the present without compromising the ability of future generations to meet their own needs" [1]. This principle is at the core of the 17 sustainable development goals (SDGs) adopted in 2015 by the United Nations (UN) General Assembly [2]. These SDGs collectively help to guide actions for global development and shape visions for the future. At the global level, the UN Statistical Commission serves as the oversight body for SDG efforts. The commission oversees the UN Statistics Division, which is responsible for the maintenance of the Global SDG Indicators Database.

In 2015, the UN Statistical Commission created the Inter-agency and Expert Group on SDGs (IAEG-SDGs), which was tasked with the development and implementation of a global indicator framework for monitoring global progress toward fulfillment of the 17 SDGs. In 2017, the UN General Assembly adopted the global indicator framework developed by the IAEG-SDGs. In the adopted 
framework, various social-ecological indicators are identified and assigned to the SDG targets [3,4]. Here, the term "social" includes both the social and economic dimensions of sustainability, whereas the term "ecological" refers to its environmental dimension. Together, these are often referred to as the three pillars of sustainability: people (social), profit (economic), and planet (environmental), respectively [5-7]. In this review, the social-ecological indicators are regarded as a set of outcomes for assessing and monitoring the sustainability of social-ecological systems (also called human-environment systems, coupled human-environment systems, and coupled human and natural systems [8,9]), analyzed in the context of the social-ecological system framework proposed by Elinor Ostrom [10-12].

Among various descriptions of indicators [13-15], one that is often cited states that "desirable indicators are those that summarize or otherwise simplify relevant information, makes [sic] visible or perceptible phenomena of interest, and quantify, measure, and communicate relevant information" [13] (p. 108). Indicators, like goals [16], should also be SMART: specific, measurable, achievable, relevant, and time-bound [17]. The major functions of indicators are to (i) assess conditions and trends, (ii) compare across places and situations, (iii) assess conditions and trends in relation to goals and targets, (iv) provide early warning information, and (v) anticipate future conditions and trends [13]. The SDG global indicator framework, though developed primarily for monitoring global progress toward achievement of the SDGs [2,4], supports all these indicator functions. More generally, sustainable development indicators are "scientific constructs whose principal objective is to inform public policy-making" [18] (p. 45).

The achievement of SDGs relies on the performance of countries with respect to the SDG targets and indicators. Thus, the development of methodologies for monitoring progress toward SDG achievement has become "a new vital science" [19]. Custodian agencies are responsible for the development of the necessary methodologies and the collection and compilation of data related to SDG indicators. The international organizations and agencies designated as custodian agencies by the IAEG-SDGs include the World Health Organization (WHO), the Food and Agriculture Organization (FAO), the United Nations Development Programme (UNDP), and the World Bank [20]. Available data for all SDG indicators are compiled in the Global SDG Indicators Database (https://unstats.un. org/sdgs/indicators/database), and the UN Statistics Division also issues annual SDG progress reports (https://unstats.un.org/sdgs/).

The global indicator framework includes a total of 231 unique indicators spread across 169 SDG targets [3,21]. Twelve indicators are associated with two or three targets [3,21]. SDG 17 (Partnerships for the Goals) has the highest number of targets, with 19, followed by SDG 3 (Good Health and Well-Being) with 13 (Figure 1). By contrast, SDGs 7 (Affordable and Clean Energy) and 13 (Climate Action) have the lowest number of targets, with five each. SDG 3 has the largest number of indicators (28), followed by SDGs 16 (Peace, Justice and Strong Institutions) and 17 (24 each), and SDGs 7 and 13 have the smallest number of indicators (6 and 8 , respectively).

The SDG indicators are classified into three tiers according to the level of methodological development and the global availability of data as follows [20]: a Tier I indicator "is conceptually clear, has an internationally established methodology and standards are available, and data are regularly produced by countries for at least 50 per cent of countries and of the population in every region where the indicator is relevant." A Tier II indicator "is conceptually clear, has an internationally established methodology and standards are available, but data are not regularly produced by countries." For a Tier III indicator, "no internationally established methodology or standards are yet available for the indicator, but methodology/standards are being (or will be) developed or tested." Indicators for which data availability is under review are labeled as "pending data availability review" [20]. 


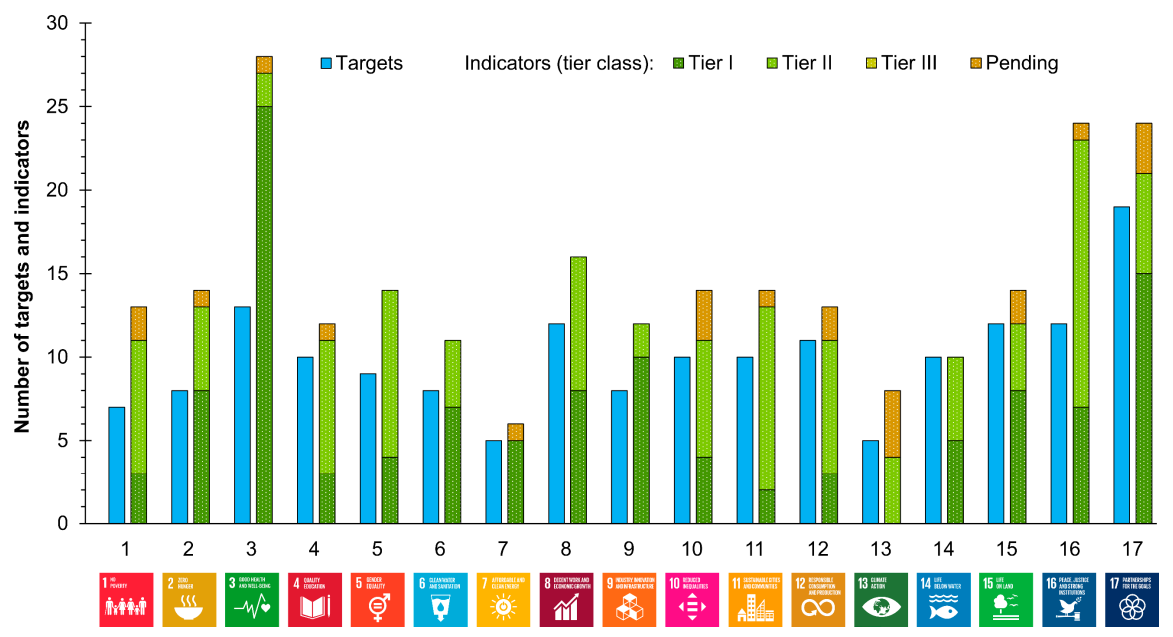

Figure 1. Distribution of targets and indicators across the 17 SDGs. These data were sourced from the March 2020 version of the global indicator framework for the SDGs [3] and the April 2020 version of the tier classification for global SDG indicators [20]. The global indicator framework was adopted by the UN General Assembly in July 2017 and is contained in the resolution designated A/RES/71/313 [4,21]. As of this writing, the latest version of the list of SDG indicators bears the following notations in the upper right corner of the downloadable PDF document: A/RES/71/313, E/CN.3/2018/2, E/CN.3/2019/2, and E/CN.3/2020/2 [3]. These notations mean that the current official list of indicators [3] includes the global indicator framework as contained in A/RES/71/313, the refinements agreed by the UN Statistical Commission at its 49th session in March 2018 (E/CN.3/2018/2, Annex II) and 50th session in March 2019 (E/CN.3/2019/2, Annex II), and the changes from the 2020 Comprehensive Review (E/CN.3/2020/2, Annex II) and annual refinements (E/CN.3/2020/2, Annex III) from the 51st session in March 2020 [21].

Explicit in the 2030 Agenda (Transforming Our World: The 2030 Agenda for Sustainable Development) is a declaration (no. 76) to support developing countries by ensuring access to high-quality, timely, reliable, and disaggregated data, including geospatial and Earth observation data [2]. Recognizing that the "integration of statistical data and geospatial information will be key for the production of a number of indicators," the IAEG-SDGs created the Working Group on Geospatial Information (WGGI) in 2016 [22] (p. 1) under the UN's Committee of Experts on Global Geospatial Information Management (UN-GGIM). The primary objective of the WGGI is "to ensure from a statistical and geospatial perspective that one of the key principles of the 2030 Agenda, to leave no one behind, is reflected in the global indicator framework" [22] (p. 2).

The Group on Earth Observations (GEO), created in 2005, is a global partnership of governments and organizations that "envisions a future where decisions and actions for the benefit of humankind are informed by coordinated, comprehensive and sustained Earth observations" (www.earthobservations. org). In 2016, recognizing the potential of Earth observation data for SDG monitoring, the GEO launched an initiative called "Earth Observations in Service of the 2030 Agenda for Sustainable Development" (EO4SDG) (http://eo4sdg.org/) [23-25]. The purpose of this initiative is to "organize and realize the potential of Earth observations and geospatial information to advance the 2030 Agenda and enable societal benefits through achievement of the Sustainable Development Goals" [25] (p. 4). The EO4SDG initiative set forth three goals in its Strategic Implementation Plan 2020-2024: "(i) demonstrate how Earth observations, geospatial information, and socio-economic and other data contribute in novel and practical ways to support sustainable development efforts and the SDGs, (ii) increase skills and capabilities in uses of Earth observations for SDG activities and their broader benefits, and (iii) broaden interest, awareness, and understanding of Earth observations support to the SDGs and contributions to social, environmental, and economic benefits" [25] (p. 4).

A couple of years into the implementation of the 2030 Agenda, the GEO has seen an increasing demand for EO data for monitoring progress toward achievement of the SDGs [25]. The GEO has 
identified $71(42 \%)$ targets and $30(13 \%)$ indicators for the SDGs that can be supported, directly or indirectly, by EO data [25] (see Section 4). The EO4SDG initiative supports the WGGI task stream called "Application of Earth Observations for the SDG Indicators" [25].

The purpose of this review is to describe the conceptualization of sustainability leading to the formulation of the SDGs and then to discuss the current status, challenges, and opportunities in SDG monitoring using remote sensing (RS).

\section{Review Approach}

This review is intended to be an overview, that is, a survey of the literature and a description of its characteristics [26]. The search and appraisal of reference materials for this review did not follow a set of pre-defined rules as would be done for a systematic review. Potentially relevant reference materials were searched online and appraised according to whether they included information on the conceptualization of sustainability and SDG monitoring with RS. This review thus aims to provide a broad introductory understanding of (a) the conceptualization of sustainability leading to the formulation of the SDGs, (b) the role of RS in SDG monitoring, and (c) the current status, challenges, and opportunities of SDG monitoring with RS.

\section{From the Conceptualization of Sustainability to the Formulation of the SDGs}

This section provides an overview of the historical origin and development of the sustainability concept and the progression that eventually led to the formulation of the SDGs. In the past three decades, a number of works have addressed this topic. Kidd [27], who focused on the development of the sustainability concept in the 19th and 20th centuries, suggested that the concept has its origins in six ideas (termed "roots"): the ecological/carrying capacity root, the resource/environment root, the biosphere root, the critique of technology root, the no growth-slow growth root, and the ecodevelopment root. According to Grober [28], the sustainability concept probably originated in the 17th and 18th centuries when declining forests in Europe led to the idea that sustained yield (or sustainable use) of forest resources could be achieved through conservation and reforestation. Warde [29], however, thought that the "invention of sustainability" might have occurred earlier, between c. 1500 and 1870 .

A timeline of the conceptual development of sustainability (Figure 2) shows that before 1970, the literature on sustainability was dominated by books and essays, whereas after 1970, peer-reviewed articles and global policy initiatives and reports became more dominant. Indeed, environmental issues and initiatives reached the global stage when the UN General Assembly convened in the 1972 Stockholm Conference. Before this conference, environmental governance was apparently not considered to be an international priority. The Stockholm Conference led to the Declaration on the Human Environment (Stockholm Declaration) and resulted in the creation of the UN Environment Programme (UNEP), which is today "the global champion for the environment with programmes focusing on sustainable development, climate, biodiversity and more" (www.unenvironment.org).

Historically, the sustainability concept has its roots in the works of English author John Evelyn (Sylva, 1664) and the French statesman Jean Baptist Colbert (Ordonnance, 1669), who called for the re-establishment and conservation of forests [28,30] (Figure 2). Although the focus of these works was on Europe, both books included the idea that the current generation has responsibility for future generations [28]. Moreover, they were important sources and models for German nobleman Hanns Carl von Carlowitz [28]. In 1713, von Carlowitz published Sylvicultura Oeconomica, in which he introduced the term "sustainable" in its modern sense for the first time: in German, "nachhaltende Nutzung," referring to the "sustainable use" [31] or "sustained use" [28] of forest resources. During the 18th century, nachhaltend was modified to nachhaltig, and the use of the related noun nachhaltigkeit, with reference to "sustained yield" forestry, became widespread [28]. Today, nachhaltigkeit is generally translated as "sustainability." 


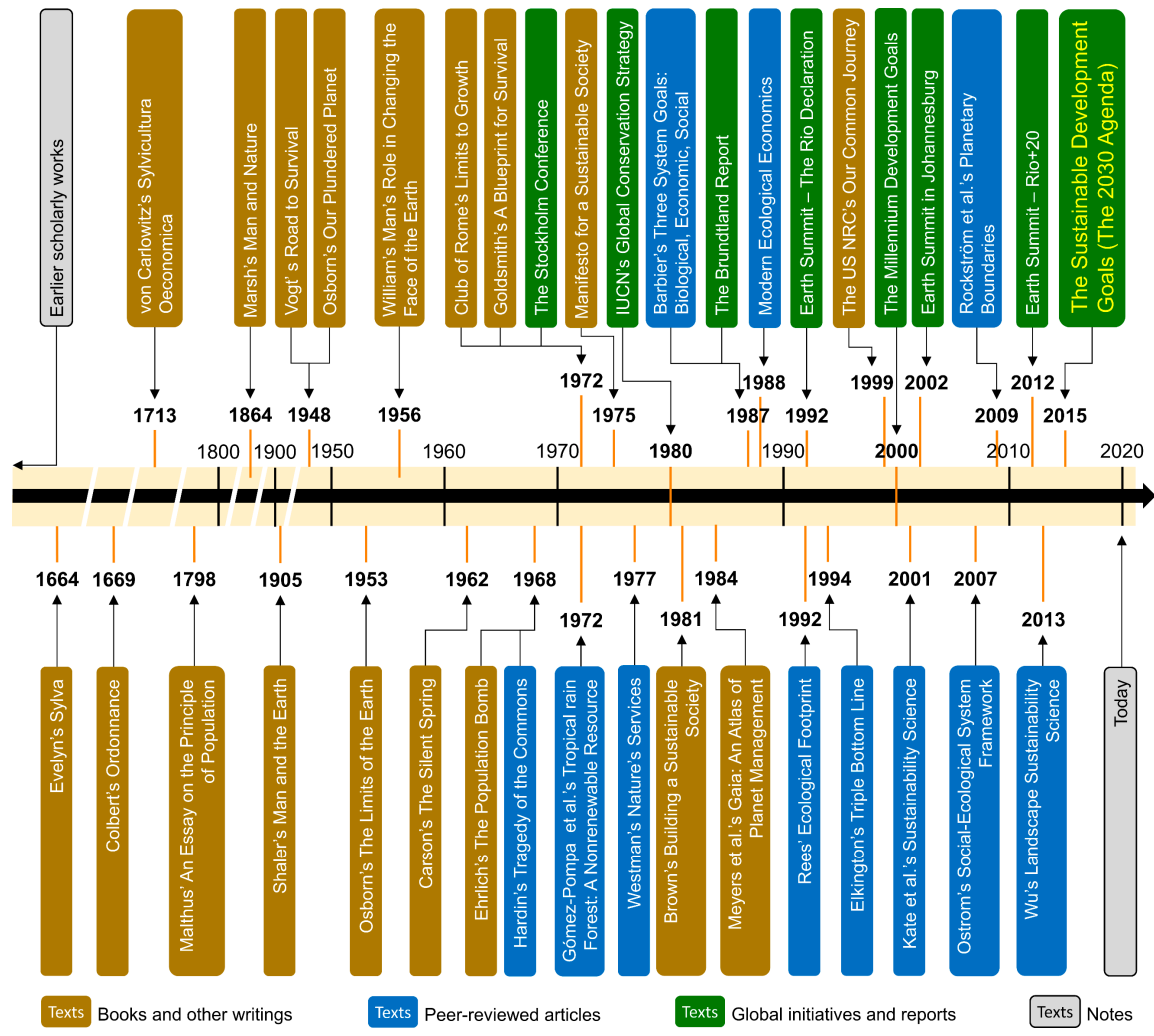

Figure 2. Timeline showing how the sustainability concept has been advanced by scholarly works and global policy initiatives.

Over the past three centuries, many influential books have contributed to the development of the sustainability concept as we understand it today (Figure 2). These include An Essay on the Principle of Population (1798) by Thomas Robert Malthus, Man and Nature (1864) by George Perkins Marsh, Man and the Earth (1905) by Nathaniel Shaler, Road to Survival (1948) by William Vogt, Our Plundered Planet (1948) and The Limits of the Earth (1953) by Fairfield Osborn, Man's Role in Changing the Face of the Earth (1956) by William L. Thomas, Jr., The Silent Spring (1962) by Rachel Carson, The Population Bomb (1968) by Paul R. Ehrlich and Anne H. Ehrlich, Limits to Growth (1972) by the Club of Rome, and A Blueprint for Survival (1972) by Edward Goldsmith and Robert Allen. Reviews of the sustainability concept and its origin, including the conceptualization of sustainable development, commonly cite these books [27,30,31]. However, the term "sustainable development," as presented in the Brundtland Report (1987) [1], was first used in World Conservation Strategy, published in 1980 by the International Union for Conservation of Nature (IUCN) [32]. Other works contributing to the conceptualization of sustainable development include Building a Sustainable Society (1981) by Lester R. Brown and Gaia: An Atlas of Planet Management (1984) by Norman Meyers and colleagues [31].

Among articles in peer-reviewed journals that have helped shape and advance the sustainability concept, "The tragedy of the commons" (1968) [33] was one of the earliest and most influential. The "tragedy of the commons" is that, in the absence of proper regulation, self-interest can lead to the over-exploitation and destruction of non-renewable common resources, such as the atmosphere, the ocean, and biodiversity, threatening their sustainability. "Tropical rain forest: A nonrenewable resource" (1972) [34] emphasized the importance of tropical rainforests as a non-renewable resource. "How much are nature's services worth?" [35] introduced the concept of nature's services, which, together with some other works [36,37], led to the "ecosystem services" concept [38]. Interestingly, the Intergovernmental Science-Policy Platform on Biodiversity and Ecosystem Services (IPBES) recently proposed, without referring to these earlier works, "nature's contribution to people" as an umbrella term that also includes ecosystem services $[39,40]$. The ecosystem services concept gained popularity with the publication of 
the book Nature's Services: Societal Dependence on Natural Ecosystems (1997) [41], the article "The value of the world's ecosystem services and natural capital", which appeared in Nature in 1997 [42], and the Millennium Ecosystem Assessment report in 2005 (www.millenniumassessment.org/).

Several important ideas have helped advance the sustainability concept. In 1987, Barbier [5] introduced the three system goals of sustainability (biological and resource, economic, and social), which might be the origin of the idea that there are three pillars, dimensions, components, or aspects of sustainability [30,43]. Along with Barbier's work [5], the notion of the triple bottom line [6,7] also contributed to the idea that there are three pillars of sustainability. Ecological economics, a transdisciplinary field of study [44,45], has helped advance the concept of natural capital, a term first used by Ernst F. Schumacher in his book Small is Beautiful (1973). The ecological footprint concept [46] eventually led to the establishment of the global footprint network, which aims to advance the science of sustainability. The term "sustainability science" [47] was introduced in Our Common Journey: A Transition Toward Sustainability (1999) by the US National Research Council (NRC) [48]. The field of sustainability science has since been advanced by the development of the social-ecological system framework [10] which couples human and environmental systems. In this context, the planetary boundaries concept [49] aims to define a safe operating space for humanity, and landscape sustainability science [50] focuses on the dynamic relationship between ecosystem services and human well-being.

The development of the idea of the human-environment system, together with global initiatives such as the Earth Summit and the Millennium Development Goals (MDGs) (see Figure 2), have helped advance the field of sustainability science and influenced the formulation of the current SDGs. In particular, the three pillars of sustainability are explicitly embedded in the formulation of the SDGs $[30,51]$. However, the sustainability (or sustainable development) concept is frequently criticized as vague and ambiguous [52-56]. These critiques ask, the sustainability of what and for whom? This reviewer argues that, in the context of the SDGs, sustainability means the sustainability of Earth's resources-its life-support system - for the benefit, or at least for the survival, of the current and future generations of humankind.

In their comprehensive review on the conceptual evolution of sustainability, Purvis et al. [30] suggest that the concepts of the three pillars of sustainability (social, economic, and environmental) do not have theoretically rigorous support, and they conclude that "the absence of such a theoretically solid conception frustrates approaches towards a theoretically rigorous operationalisation of 'sustainability'" [30] (p. 681). This reviewer recognizes this issue. Nevertheless, the viewpoint of this reviewer is that the idea of sustainability is of great importance to humanity, because, like the concepts of freedom, justice, and democracy, which are also dialectically vague, it expresses a fundamental principle that can guide our actions and shape our visions for the future [50,57].

\section{The Role of Remote Sensing for SDG Monitoring}

The development of a "human capability to observe regions of the electromagnetic spectrum outside the range of wavelengths discernable by the human eye" was fundamental to the evolution of remote sensing technology [58] (p. 685). The term "remote sensing" was coined in the 1950s by Evelyn Pruitt, a geographer and oceanographer formerly with the Office of Naval Research (https://earthobservatory.nasa.gov/features/RemoteSensing). According to Gerald K. Moore [59] (p. 478), remote sensing is "the use of reflected and emitted energy to measure the physical properties of distant objects and their surroundings". The Encyclopedia of Remote Sensing defines remote sensing as "the technique of obtaining information about objects through the analysis of data collected by special instruments that are not in physical contact with the objects of investigation" [58] (p. 684). Nicholas M. Short, in his Remote Sensing Tutorial (An Online Handbook), has defined remote sensing as "the acquisition and measurement of data/information on some property(ies) of a phenomenon, object, or material by a recording device not in physical, intimate contact with the feature(s) under surveillance; techniques involve amassing knowledge pertinent to environments by measuring force fields, electromagnetic radiation, or acoustic energy employing cameras, radiometers and scanners, 
lasers, radio frequency receivers, radar systems, sonar, thermal devices, seismographs, magnetometers, gravimeters, scintillometers, and other instruments."

Remote sensing (RS) is multi-functional because it is (1) a source of basic data, (2) a science, and (3) a tool. RS is a source of basic data because the measurements of physical properties of distant objects and their surroundings with the use of reflected and emitted energy are themselves data, regardless of where they are recorded [59]. RS is a science because it utilizes a scientific process: measurements, data processing, interpretation of the results, and scientific inference [59]. Finally, RS is a tool because results obtained from this scientific process can be used for various purposes, from the making of inventories of resources to the solving of ecological problems [59].

Monitoring of the SDG indicators is vital, and Earth observation technologies such as RS have an important role to play in indicator monitoring. RS data are particularly useful because they can be used for both temporal and spatial monitoring. As early as two decades ago, before the formulation of the SDGs [2,51] and launch of the EO4SDG initiative [23-25], and also before the development of concepts such as "seeing sustainability from space" [60] and "remote sensing for sustainability" [61], Rao [62] foresaw the potential of RS technology for sustainability-related research and for helping to achieve sustainable development. Through the EO4SDG initiative, the potential of RS technology is now being explored at a global scale. RS-derived data have been shown to be useful across many fields, such as in the field of land cover monitoring and ecosystem assessment [63-71], hydrological studies [72,73], meteorological/climatological and climate change studies [74,75], thermal and urban remote sensing [76-85], air quality monitoring [86,87], health geographics [88-91], and disaster risk management $[92,93]$.

The importance of EO technologies such as RS has become more apparent with the formulation of the SDG framework, compared with their importance to its predecessor, the Millennium Development Goals (MDG) framework (www.un.org/millenniumgoals/). Although the MDG framework helped narrow the data gap with regard to the social dimension of sustainability, the inclusion of various environmental indicators under the SDG targets has increased the need for accurate, timely, and reliable environmental data. RS is an important environmental monitoring tool that can help fill gaps in environmental data $[24,25,94]$.

Some essential characteristics of RS data have important advantages for SDG monitoring: spatial resolutions ranging from coarse to very high; temporal resolutions ranging from ca. bimonthly to daily; various spectral resolutions; spatial scales from local to global; long-period time series (starting from 1972 for Landsat); consistency (in terms of data capture or measurement); and complementarity (ability to be validated) [95] (Tables A1 and A2). These features mean that RS data are useful for the development of policy-relevant environmental SDG indicators $[94,95]$ that can be monitored over space and time.

The 30 social-ecological indicators that can be directly or indirectly supported by EO data [25] are related to 13 SDGs (Figures 3 and A1). Among these 13 SDGs, SDGs 6 (Clean Water and Sanitation), 11 (Sustainable Cities and Communities), 14 (Life Below Water), and 15 (Life on Land) offer "the greatest opportunities for the application of EO data" [25] (p. 8). Information on the current status of these RS-based indicators is given in Section 5 and Figure 3.

In general, the monitoring of progress toward achieving the SDGs by way of the SDG global indicator framework increases the demand for various statistical data from countries all over the world. This increased demand for these data necessitates an increase in investments of money, manpower, and time in building the capacity of national statistical offices-investments that might be better made in research and substantive development projects with clear impacts on meeting SDG targets [96]. In this regard, the EO4SDG initiative is especially important for developing regions that have low capacity for database development. Moreover, the potential use of EO data for more indicators, in addition to the 30 indicated currently identified as EO-supported, presents valuable opportunities in research and development (details are discussed in Section 5). 


\begin{tabular}{|c|c|c|c|c|c|c|}
\hline & Goal & & & Idicators & & \\
\hline 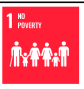 & No Poverty & $\begin{array}{l}1.4 .2^{\circ} \\
\text { Tier II }\end{array}$ & & & & \\
\hline 2 IIII & Zero Hunger & $\begin{array}{l}2.4 .1^{\circ} \\
\text { Tier II }\end{array}$ & & & & \\
\hline$-W^{6}$ & Good Health and Well-Being & $\begin{array}{c}{ }^{3.9 .1}{ }^{\circ} \\
\text { Tier I }\end{array}$ & & & & \\
\hline 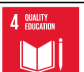 & Quality Education & & & & & \\
\hline 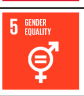 & Gender Equality & $\begin{array}{l}\text { 5.a.1 } \\
\text { Tier II }\end{array}$ & & & & \\
\hline 6 & Clean Water and Sanitation & $\begin{array}{l}6.3 .1^{\circ} \\
\text { Tier II }\end{array}$ & $\begin{array}{l}6.3 .2^{\circ} \\
\text { Tier II }\end{array}$ & $\begin{array}{l}6.4 .2^{\circ} \\
\text { Tier }{ }^{\circ}\end{array}$ & $\begin{array}{c}6.5 .1^{\circ} \\
\text { Tier I }\end{array}$ & $\begin{array}{l}6.6 .1^{\circ} \\
\text { Tier I }\end{array}$ \\
\hline 7 प' & Affordable and Clean Energy & $\begin{array}{c}7.1 .1^{\circ} \\
\text { Tier I }\end{array}$ & & & & \\
\hline 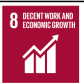 & Decent Work and Economic Growth & & & & & \\
\hline 9 & Industry, Innovation and Infrastructure & $\begin{array}{l}9.1 .1^{\circ} \\
\text { Tier II }\end{array}$ & $\begin{array}{c}9.4 .1^{\circ} \\
\text { Tier } 1\end{array}$ & & & \\
\hline 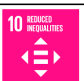 & Reduced Inequalities & & & & & \\
\hline An & Sustainable Cities and Communities & $\begin{array}{c}11.1 .1 \\
\text { Tier I }\end{array}$ & $\begin{array}{c}11.2 .1 \\
\text { Tier II }\end{array}$ & $\begin{array}{c}11.3 .1 \\
\text { Tier II }\end{array}$ & $\begin{array}{c}11.6 .2^{\circ} \\
\text { Tier I }\end{array}$ & $\begin{array}{l}\text { 11.7.1 }^{\circ} \\
\text { Tier II }\end{array}$ \\
\hline$\frac{12}{a 0}$ & Responsible Consumption and Production & $\begin{array}{c}\text { 12.a.1 } \\
\text { Tier Pending }\end{array}$ & & & & \\
\hline 8 & Climate Action & $\begin{array}{c}13.1 .1 \\
\text { Tier II }^{\circ} \\
\end{array}$ & & & & \\
\hline 14 & Life Below Water & $\begin{array}{c}14.1 .1^{\circ} \\
\text { Tier II }\end{array}$ & $\begin{array}{c}14.3 .1 \\
\text { Tier II }\end{array}$ & $\begin{array}{c}14.4 .1 \\
\text { Tier I }\end{array}$ & $\begin{array}{c}14.5 .1 \\
\text { Tier I }\end{array}$ & \\
\hline 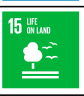 & Life on Land & $\begin{array}{c}15.1 .1^{\circ} \\
\text { Tier I }\end{array}$ & $\begin{array}{c}15.2 .1 \\
\text { Tier I }\end{array}$ & $\begin{array}{c}15.3 .1 \\
\text { Tier I }\end{array}$ & $\begin{array}{c}15.4 .1 \\
\text { Tier I }\end{array}$ & $\begin{array}{c}15.4 .2^{\circ} \\
\text { Tier I }\end{array}$ \\
\hline $\begin{array}{c}10 \\
y_{1}\end{array}$ & Peace, Justice and Strong Institutions & & & & & \\
\hline 8 & Partnerships for the Goals & $\begin{array}{c}17.6 .1^{\circ} \\
\text { Tier I }\end{array}$ & $\begin{array}{c}\text { '0 } \\
17.18 .1 \\
\text { Tier Pending }\end{array}$ & & & \\
\hline
\end{tabular}

Data availability (as of April 2020)

$\square$ Available $\square$ Not available
Inclusion in the 2019 SDG Index and Dashboards

○ Included (exact indicator) $\bigcirc$ Included (proxy indicator) ○ Not included

Figure 3. Current status of the RS-based SDG indicators. This list of indicators is based on GEO [25]. Data availability is based on the Global SDG Indicators Database as of April 2020 (https://unstats.un. org/sdgs/indicators/database/). The 2019 SDG Index and Dashboards are available in the Sustainable Development Report 2019 [97]. The tier classification of the indicators are those as of April 2020 [20].

\section{Current Status, Challenges, and Opportunities}

\subsection{Status of the 2030 Agenda}

Just under 10 years remain to achieve the 2030 Agenda. The UN Global Sustainable Development Report 2019 (UN-GSDR 2019) [98] has concluded that (i) despite initial efforts, the world is not on track for achieving most of the 169 targets that comprise the SDGs, (ii) recent trends along several dimensions with cross-cutting impacts across the entire 2030 Agenda (rising inequalities, climate change, biodiversity loss, and increasing amounts of waste from human activity) are not even moving in the right direction, (iii) under current trends, the world's social and natural biophysical systems 
cannot support the aspirations for universal human well-being embedded in the SDGs, and (iv) no country is yet convincingly able to meet a set of basic human needs at a globally sustainable level of resource use.

To achieve the desired transformations at the necessary scale and speed, the UN-GSDR 2019 identifies six entry points: human well-being and capabilities, sustainable and just outcomes, food systems and nutrition patterns, energy decarbonization with universal access, urban and peri-urban development, and global environmental commons [98]. It also identifies four levers that "can be coherently deployed through each entry point to bring about the necessary transformations": governance, economy and finance, individual and collective action, and science and technology [98] (p. xxi).

The report also highlights the importance of sustainability science [47] to "help tackle the trade-offs and contested issues involved in implementing the 2030 Agenda." Accordingly, "new initiatives are needed that bring together science communities, policymakers, funders, representatives of lay, practical and indigenous knowledge and other stakeholders to scale up sustainability science and transform scientific institutions towards engaged knowledge production for sustainable development." To achieve this, the UN "should launch a globally coordinated knowledge platform to synthesize existing international and country-by-country expertise on transformation pathways from scientific and nonscientific sources, including lay, practical and indigenous knowledge," and, at the same time, "educational institutions at every level, especially universities, should incorporate high-quality theoretical and practically oriented courses of study on sustainable development" [98] (p. 120).

One feedback on the UN-GSDR 2019 relates to the effort paid to the improvement of the SDG global indicator framework, because although there are frequent opportunities for input, clarity and transparency on the dynamics of decision-making is less frequent [96]. The fear is that more is being invested in the development of the SDG global indicator framework, including its databases, than is being invested in actual projects that can deliver desirable outcomes and bring about progress, and, as a result, "many of the targets will not only not be met, but unless things change radically, will never be met" [96] (p. 5).

The standpoint of this reviewer is that, although both the refinement of the SDG global indicator framework and the development of relevant databases are necessary to enable the monitoring of progress toward the SDGs, these activities should not overshadow the need to implement projects needed to help achieve the SDGs and which can be expected to have actual and positive impacts on people's lives, society, and the environment.

\subsection{Status of the RS-Based Indicators and Their Inclusion in the SDG Index 2019}

As of April 2020, 21 (70\%) of the 30 RS-based SDG indicators have at least some preliminary statistical data, according to the Global SDG Indicators Database (Figure 3; Table 1). Among those indicators with statistical data, 16 are classified as Tier 1 and five as Tier II indicators. Among the nine indicators still without statistical data, seven are Tier II indicators and the tier classification of the other two is pending. None of the 30 RS-based indicators is currently classified as a Tier III indicator [20].

The SDG indicators are also being monitored indirectly by the UN Sustainable Development Solutions Network (SDSN), in partnership with the Bertelsmann Stiftung (BS), which produces annual reports that assess each country's performance on the 17 SDGs [97]. The mission of the SDSN, which was set up in 2012 at the direction of the UN Secretary-General, is to "mobilize global scientific and technological expertise to promote practical solutions for sustainable development, including the implementation of the SDGs and the Paris Climate Agreement" (www.unsdsn.org). The SDG Index and Dashboards (SDR-ID 2019) includes 10 (33\%) of the RS-based indicators (Figure 3) [97]; six of these exactly match official SDG indicators, and the other four are proxy indicators that are related to or closely aligned with official indicators. 
Table 1. Status of remote sensing (RS)-based sustainable development goals (SDG) indicators. Only those indicators with data as of April 2020, according to the Global SDG Indicators Database (https: //unstats.un.org/sdgs/indicators/database/), are included. The complete list of RS-based SDG indicators is given in Figure 3. The custodian and tier classification information is current as of April 2020 [20]. The number of countries/territories/regions is for the described variable only.

\begin{tabular}{|c|c|c|c|c|c|}
\hline \multirow[b]{2}{*}{ RS-based SDG Indicator } & \multirow[b]{2}{*}{ Custodian } & \multirow[b]{2}{*}{ Tier } & \multicolumn{3}{|c|}{ Available Data } \\
\hline & & & No. and Name of Data Variables & Year & $\begin{array}{c}\text { No. of } \\
\text { Countries/Territories/ } \\
\text { Regions }\end{array}$ \\
\hline $\begin{array}{l}\text { 3.9.1 Mortality rate } \\
\text { attributed to household } \\
\text { and ambient air pollution }\end{array}$ & WHO & I & $\begin{array}{c}6 \\
\text { The } 6 \text { th variable is the crude death } \\
\text { rate attributed to household and } \\
\text { ambient air pollution }\end{array}$ & 2016 & 219 \\
\hline $\begin{array}{l}\text { 5.a.1 (a) Proportion of total } \\
\text { agricultural population } \\
\text { with ownership or secure } \\
\text { rights over agricultural } \\
\text { land, by sex; and (b) share } \\
\text { of women among owners } \\
\text { or rights-bearers of } \\
\text { agricultural land, by type } \\
\text { of tenure }\end{array}$ & FAO & II & $\begin{array}{l}2 \\
\text { The 1st variable is proportion of } \\
\text { people with ownership or secure } \\
\text { rights over agricultural land, by } \\
\text { sex }\end{array}$ & $\begin{array}{l}2009-2019 \\
\text { (varies } \\
\text { by } \\
\text { country/ } \\
\text { territory) }\end{array}$ & $\begin{array}{c}10 \\
\text { (total for all data } \\
\text { years) }\end{array}$ \\
\hline $\begin{array}{c}\text { 6.3.1 Proportion of } \\
\text { wastewater safely treated }\end{array}$ & $\begin{array}{l}\text { WHO, } \\
\text { UN-Habitat, } \\
\text { UNSD }\end{array}$ & II & $\begin{array}{c}1 \\
\text { Proportion of safely treated } \\
\text { domestic wastewater flows }\end{array}$ & 2018 & 79 \\
\hline $\begin{array}{l}\text { 6.3.2 Proportion of bodies } \\
\text { of water with good } \\
\text { ambient water quality }\end{array}$ & UNEP & II & $\begin{array}{c}4 \\
\text { The 1st variable is proportion of } \\
\text { bodies of water with good } \\
\text { ambient water quality }\end{array}$ & 2017 & 52 \\
\hline $\begin{array}{l}\text { 6.4.2 Level of water stress: } \\
\text { freshwater withdrawal as } \\
\text { a proportion of available } \\
\text { freshwater resources }\end{array}$ & FAO & I & $\begin{array}{l}1 \\
\text { Level of water stress: freshwater } \\
\text { withdrawal as a proportion of } \\
\text { available freshwater resources }\end{array}$ & $\begin{array}{l}2000 \\
2005 \\
2010 \\
2015\end{array}$ & $\begin{array}{c}269 \\
(2015)\end{array}$ \\
\hline $\begin{array}{l}\text { 6.5.1 Degree of integrated } \\
\text { water resources } \\
\text { management } \\
\text { implementation }(0-100)\end{array}$ & UNEP & I & $\begin{array}{c}2 \\
\text { The 1st variable is degree of } \\
\text { integrated water resources } \\
\text { management implementation }\end{array}$ & 2018 & 182 \\
\hline $\begin{array}{l}\text { 6.6.1 Change in the extent } \\
\text { of water-related } \\
\text { ecosystems over time }\end{array}$ & $\begin{array}{l}\text { UNEP, } \\
\text { Ramsar }\end{array}$ & I & $\begin{array}{c}16 \\
\text { The } 4 \text { th variable is nationally } \\
\text { derived proportion of water } \\
\text { bodies with good quality }\end{array}$ & 2017 & 28 \\
\hline $\begin{array}{c}\text { 7.1.1 Proportion of } \\
\text { population with access to } \\
\text { electricity }\end{array}$ & $\begin{array}{l}\text { World } \\
\text { Bank }\end{array}$ & I & $\begin{array}{c}1 \\
\text { Proportion of population with } \\
\text { access to electricity, by urban/rural } \\
3\end{array}$ & $\begin{array}{l}\text { 2000-2017 } \\
\text { (annual) }\end{array}$ & $\begin{array}{c}236 \\
(2017)\end{array}$ \\
\hline $\begin{array}{l}\text { 9.4.1 } \mathrm{CO}_{2} \text { emission per } \\
\text { unit of value added }\end{array}$ & $\begin{array}{l}\text { UNIDO, } \\
\text { IEA }\end{array}$ & I & $\begin{array}{c}\text { The 3rd variable is } \mathrm{CO}_{2} \text { emissions } \\
\text { per unit of manufacturing value } \\
\text { added }\end{array}$ & $\begin{array}{l}\text { 2000-2017 } \\
\text { (annual) }\end{array}$ & $\begin{array}{c}182 \\
(2017)\end{array}$ \\
\hline $\begin{array}{l}\text { 11.1.1 Proportion of urban } \\
\text { population living in slums, } \\
\text { informal settlements or } \\
\text { inadequate housing }\end{array}$ & UN-Habitat & I & $\begin{array}{c}1 \\
\text { Proportion of urban population } \\
\text { living in slums }\end{array}$ & $\begin{array}{l}2000 \\
2005 \\
2010 \\
2014 \\
2016\end{array}$ & $\begin{array}{c}126 \\
(2016)\end{array}$ \\
\hline $\begin{array}{l}\text { 11.6.2 Annual mean levels } \\
\text { of fine particulate matter } \\
\text { (e.g. PM2.5 and PM10) in } \\
\text { cities (population } \\
\text { weighted) }\end{array}$ & WHO & I & $\begin{array}{l}1 \\
\text { Annual mean levels of fine } \\
\text { particulate matter in cities, urban } \\
\text { population }\end{array}$ & 2016 & 215 \\
\hline $\begin{array}{l}\text { 13.1.1 Number of deaths, } \\
\text { missing persons and } \\
\text { directly affected persons } \\
\text { attributed to disasters per } \\
\text { 100,000 population }\end{array}$ & UNDRR & II & $\begin{array}{l}10 \\
\text { The 2nd variable is number of } \\
\text { deaths and missing persons } \\
\text { attributed to disasters per } 100,000 \\
\text { population }\end{array}$ & $\begin{array}{l}\text { 2005-2018 } \\
\text { (annual) }\end{array}$ & $\begin{array}{c}43 \\
(2018)\end{array}$ \\
\hline $\begin{array}{l}\text { 14.3.1 Average marine } \\
\text { acidity }(\mathrm{pH}) \text { measured at } \\
\text { agreed suite of } \\
\text { representative } \\
\text { sampling stations }\end{array}$ & IOC-UNESCC & O II & $\begin{array}{c}1 \\
\text { Average marine acidity }(\mathrm{pH}) \\
\text { measured at agreed suite of } \\
\text { representative sampling stations }\end{array}$ & $\begin{array}{l}\text { 2010-2019 } \\
\text { (annual) }\end{array}$ & $\begin{array}{c}3 \\
(2019)\end{array}$ \\
\hline
\end{tabular}


Table 1. Cont.

\begin{tabular}{|c|c|c|c|c|c|}
\hline \multirow[b]{2}{*}{ RS-based SDG Indicator } & \multirow[b]{2}{*}{ Custodian } & \multirow[b]{2}{*}{ Tier } & \multicolumn{3}{|c|}{ Available Data } \\
\hline & & & No. and Name of Data Variables & Year & $\begin{array}{c}\text { No. of } \\
\text { Countries/Territories/ } \\
\text { Regions }\end{array}$ \\
\hline $\begin{array}{l}\text { 14.4.1 Proportion of fish } \\
\text { stocks within } \\
\text { biologically } \\
\text { sustainable levels }\end{array}$ & FAO & I & $\begin{array}{c}1 \\
\text { Proportion of fish stocks within } \\
\text { biologically sustainable levels (not } \\
\text { overexploited) } \\
3\end{array}$ & $\begin{array}{l}\text { 2000-2017 } \\
\text { (varied } \\
\text { interval) }\end{array}$ & $\begin{array}{c}1 \\
\text { (global) }\end{array}$ \\
\hline $\begin{array}{l}14.5 .1 \text { Coverage of } \\
\text { protected areas in relation } \\
\text { to marine areas }\end{array}$ & $\begin{array}{l}\text { UNEP-WCMC, } \\
\text { UNEP, } \\
\text { IUCN }\end{array}$ & I & $\begin{array}{l}\text { The 2nd variable is coverage of } \\
\text { protected areas in relation to } \\
\text { marine areas (Exclusive Economic } \\
\text { Zones) }\end{array}$ & 2018 & 192 \\
\hline $\begin{array}{l}\text { 15.1.1 Forest area as a } \\
\text { proportion of total } \\
\text { land area }\end{array}$ & FAO & I & $\begin{array}{l}3 \\
\text { The 2nd variable is forest area as a } \\
\text { proportion of total land area }\end{array}$ & $\begin{array}{l}2000 \\
2005 \\
2010 \\
2015\end{array}$ & $\begin{array}{c}292 \\
(2015)\end{array}$ \\
\hline $\begin{array}{l}\text { 15.2.1 Progress towards } \\
\text { sustainable forest } \\
\text { management }\end{array}$ & FAO & I & $\begin{array}{c}5 \\
\text { The 4th variable is proportion of } \\
\text { forest area with a long-term } \\
\text { management plan }\end{array}$ & $\begin{array}{l}2000 \\
2005 \\
2010\end{array}$ & $\begin{array}{c}292 \\
(2010)\end{array}$ \\
\hline $\begin{array}{c}\text { 15.3.1 Proportion of land } \\
\text { that is degraded over total } \\
\text { land area }\end{array}$ & UNCCD & I & $\begin{array}{c}1 \\
\text { Proportion of land that is } \\
\text { degraded over total land area }\end{array}$ & 2015 & 294 \\
\hline $\begin{array}{l}\text { 15.4.1 Coverage by } \\
\text { protected areas of } \\
\text { important sites for } \\
\text { mountain biodiversity }\end{array}$ & $\begin{array}{l}\text { UNEP-WCMC, } \\
\text { UNEP, } \\
\text { IUCN }\end{array}$ & I & $\begin{array}{c}1 \\
\text { Average proportion of Mountain } \\
\text { Key Biodiversity Areas covered } \\
\text { by protected areas }\end{array}$ & $\begin{array}{l}\text { 2000-2019 } \\
\text { (annual) }\end{array}$ & $\begin{array}{c}197 \\
(2019)\end{array}$ \\
\hline $\begin{array}{l}\text { 15.4.2 Mountain Green } \\
\text { Cover Index }\end{array}$ & FAO & I & $\begin{array}{c}3 \\
\text { The 1st variable is Mountain } \\
\text { Green Cover Index }\end{array}$ & 2017 & 276 \\
\hline $\begin{array}{l}\text { 17.6.1 Fixed Internet } \\
\text { broadband subscriptions } \\
\text { per } 100 \text { inhabitants, } \\
\text { by speed }\end{array}$ & ITU & I & $\begin{array}{l}2 \\
\text { The 1st variable is fixed Internet } \\
\text { broadband subscriptions per } 100 \\
\text { inhabitants, by speed }\end{array}$ & $\begin{array}{l}\text { 2000-2018 } \\
\text { (annual) }\end{array}$ & $\begin{array}{c}179 \\
(2018)\end{array}$ \\
\hline
\end{tabular}

Twelve RS-based indicators that have statistical data according to the Global SDG Indicators Database are not included in the SDR-ID 2019. These include nine Tier I indicators. Recent updates to the Global SDG Indicators Database may partly explain this inconsistency between these two monitoring platforms. However, one indicator (i.e., 11.2.1) that, according to the Global SDG Indicators Database, had no data as of April 2020 is included in the SDR-ID 2019 [97]. Overall, the information in these two monitoring platforms considered in combination (Figure 3; Table 1) is indicative of the current status of EO contributions to SDG progress monitoring at the global level. Clearly, there is more that needs to be done.

The set of criteria used to select indicators for inclusion in the SDR-ID 2019 might also account for some of the inconsistency between the two monitoring platforms. These criteria were (i) global relevance and applicability to a broad range of country settings, (ii) statistical adequacy, (iii) timeliness, (iv) data quality, and (v) coverage [97]. Given these criteria, it is surprising that indicator 15.1.1 (forest area as a proportion of total land area) was not included in the SDR-ID 2019 (Figure 3) [97], because forest cover data are available in Forest Resources Assessment (FRA) reports (www.fao.org/ forest-resources-assessment) published by the FAO-the custodian for indicator 15.1.1 (Table 1) [20]. Unfortunately, the SDR-ID 2019 does not provide any explanation.

Here, some important issues regarding SDG indicator 15.1.1 are highlighted. It is important to note that the forest cover data available in the FRA reports are based on statistics consolidated from country reports, which are not backed up by publicly available geospatial data. For the upcoming 2020 FRA report, FAO is "conducting a participatory global remote sensing survey (FRA 2020 RSS) with the scope of improving estimates of forest area change at global and regional scales." Accordingly, "the FRA secretariat, in collaboration with the Joint Research Center of the European Commission (JRC) and the FAO working group on remote sensing, has developed a worldwide methodology for the FRA 2020 RSS, which is also scalable to national assessments" (http: 
//www.fao.org/forest-resources-assessment/remote-sensing/fra-2020-remote-sensing-survey/en/). A switch to a collaborative remote sensing survey approach with the use of a harmonized method for forest cover mapping is necessary so that forest cover change statistics reported in the future will be comparable across countries, landscapes, and forest monitoring studies that employ RS technologies. More importantly, so that such statistics will be backed up by publicly available geospatial data. At present, forest cover change statistics from the FRA reports are neither comparable nor backed up by publicly available geospatial data.

One major challenge to the implementation of the new approach is the harmonization of the definition of forest. The FAO defines a forest in terms of both tree cover and land use; a forest may include bare areas where trees are expected to regenerate, but areas with tree cover in agricultural or urban land use classes are excluded [65,99]. In contrast, RS-based data (e.g., Global Forest Watch) define forest only in terms of tree cover [63,99]. Harmonization of the definition of forest would help clarify important but conflicting records. For instance, a recent global land change study found that global tree cover increased by 2.24 million $\mathrm{km}^{2}$ from 1982 to 2016 as a result of a net gain in the extratropics [66], but this finding contradicts FRA reports of a global decline in forest area [99]. This reported increase in global tree cover is supported, however, by another study that reported a net increase of 5.4 million $\mathrm{km}^{2}$ of new leaf area from 2000 to 2017, two-thirds of which was attributed to the greening of croplands and forests [67].

Of these two forest definitions, land use plus tree cover and tree cover alone, the latter has greater potential to harmonize methods for global forest cover monitoring with the application of RS technologies. The use of remotely sensed tree cover as the basis for mapping forest cover and monitoring changes is also timely because, as reported by the GEO in a 2017 press release, full satellite coverage of the world's forests has now been achieved, so that all countries have the data necessary for annual forest cover monitoring (https://www.earthobservations.org/article.php?id=250). Nevertheless, if the FAO continues to use the land use plus tree cover concept of forest, the view of this reviewer is that the FAO should ensure the use of a harmonized method for identifying and classifying land use from RS data, not only tree cover. It should also make sure that gross forest cover losses and gains are also reported and backed up by publicly available geospatial data (both raw and processed).

Among databases relevant to the 2030 Agenda for Sustainable Development, the Global SDG Indicators Database (https://unstats.un.org/sdgs/indicators/database/) is of primary importance. In terms of geospatial data, the data for the EO4SDG initiative are stored in the Global Earth Observation System of Systems (GEOSS) portal (www.geoportal.org). The UN's Open SDG Data Hub also stores available geospatially referenced data for each SDG (http://unstats-undesa.opendata.arcgis.com). Other sources of geospatial data include NASA's Open Data Portal (https://data.nasa.gov) and the Center for International Earth Science Information Network (CIESIN) (www.ciesin.org). Other initiatives that make SDG-relevant data available include the Global Partnership for Sustainable Development Data (www.data4sdgs.org) and the Open Data Watch (https://opendatawatch.com).

\subsection{Challenges, Opportunities, and Insights}

The production of data for the other RS-based indicators and the subsequent inclusion of more RS-based indicators in the annual updates of the SDR-ID 2019 are among the current challenges to the realization of the EO4SDG initiative. Other challenges relate to the identification and development of relevant sub-indicators or complementary indicators, because some SDG indicators are not specific enough to be properly addressed at present. For example, indicator 15.3.1, the "proportion of land that is degraded over total land area" has been identified as one of the indicators that can be supported by EO data (Figure 3; Table 1). However, land degradation itself is a broad concept, as indicated by target 15.3: "by 2030, combat desertification, restore degraded land and soil, including land affected by desertification, drought, and floods, and strive to achieve a land degradation-neutral world" [2,3].

To address this issue, three sub-indicators for indicator 15.3.1 have been identified: land cover and land cover change, land productivity, and above- and belowground carbon stocks [24,100]. With 
respect to land productivity as a sub-indicator of 15.3.1, a recent study [100] (p. 1) argues that "current use of vegetation indices alone to remotely sense degradation of ecosystem services does not provide an adequate productivity indicator"; thus a more robust methodology is needed. Another study has developed an integrated approach to the operationalization of the three proposed sub-indicators for indicator 15.3.1 [95]. In this approach, all three sub-indicators are taken into account by a modeling process that results in an overall indicator of land degradation [95].

RS data can also be used to examine and identify priority areas for sustainable management to realize targets under SDG 6 (Clean Water and Sanitation) [101]. Furthermore, RS data can also be used to provide evidence for some of the currently identified non-RS-based indicators. For instance, RS data can be used to derive relevant landscape-based indicators (e.g., landscape fragmentation and connectivity metrics) as complementary indicators for assessing the effectiveness of financial investments in the conservation and sustainable use of biodiversity and ecosystems (target 15.a), as well as in sustainable forest management, including conservation and reforestation (target 15.b). RS data can also help operationalize social and economic SDG targets. For instance, RS data can be used to advance the study and monitoring of household poverty [102], which is relevant to targets 1.1 and 1.4. An idea for assessing slavery from space, which is relevant to target 8.7, has also been proposed [103].

According to the Global SDG Indicators Database, some indicators have available data in $>200$ countries or territories, but others have available data in fewer than 50 (Table 1). Moreover, for some indicators, data are available at multiple spatial scales (regions, countries, and territories), whereas for others, data are available only for countries. To ensure consistency, geographical units for data production, collection, and reporting for global monitoring need to be harmonized across all SDG indicators. Likewise, the baseline year for all SDG indicators may also need to be defined and harmonized. Simply harmonizing the baseline year would help not only the groups that are in charge of data production and collection but also researchers interested in SDG monitoring at the global level.

It is clear that the SDG global indicator framework in general and the RS-based indicators in particular need to be improved. Other current challenges, as well as future research directions, related to SDGs, targets, and indicators include addressing the potential pitfalls (ethical, legal, and reputational) in the compilation and use of big data [104] and the analysis of synergies and trade-offs [101,105-108]. Other important issues include the development of other frameworks for assessing the suitability of EO-derived data for SDG indicators [60] and of another aggregation method for the SDG Index [108], as well as the regionalization (sub-national) of SDG progress monitoring [109]. In particular, for the possible improvement of the SDG Index as presented in the SDR-ID 2019 [97] and in its earlier versions (www.sdgindex.org), an aggregation method based on a multidimensional synthesis of indicators and that takes into account the trade-offs and synergies between goals and targets and across the three pillars of sustainable development (social, economic, and environmental) has been proposed [108]. Regionalized or localized SDG progress monitoring is also particularly important because it allows individual countries to assess their own progress in space and time toward sustainable development [109].

RS-based indicator status as presented here (Figure 3; Table 1) is based solely on the Global SDG Indicators Database. This database only consolidates available statistics at the country or territory and regional levels; it does not include information on the actual availability of the geospatial data (both raw and processed) from which the statistical data were supposedly derived. This is important to note because some of the RS-based indicators identified as already having at least preliminary statistical data (Table 1) may not yet have geospatial data. For example, data for indicator 15.1.1 (forest area as a proportion of total land area) recorded in the database are based on FRA reports, but, as mentioned earlier, these recorded statistical data are not backed up by geospatial data. Some information on the availability of geospatial data are available from the UN Open SDG Data Hub, but it would be better if the GEOSS portal provided information related to the EO4SDG initiative. As of this writing, however, no specific page is dedicated to the currently identified RS-based SDG indicators and for tracking the actual status and availability of raw and processed geospatial data for each of these indicators. 
Perhaps future updates of the EO4SDG initiative and the GEOSS portal could address this issue, in collaboration with the concerned designated SDG indicator custodians.

A limitation of this review is that it is only an overview of the conceptualization of sustainability leading to the formulation of the SDGs and of the current status, challenges, and opportunities in SDG monitoring with RS. Some important issues need to be covered at greater depth, such as (i) the applications of RS, including data availability, across ecosystems but with particular focus on the SDGs, (ii) how the number of SDG indicators might be different from one ecosystem to another, (iii) challenges and opportunities of RS data in terms spectral and spatial resolutions as applied across ecosystems, (iv) how the SDG indicators were decided (e.g., how much is based on concerns in terms of the economic, social, and environmental pillars of sustainability and how much is based on logistics, e.g., data availability), and (v) the specific issues about the SDG global indicator framework, e.g., inappropriateness of some of the (initial) indicators.

\section{Conclusions}

Although the concept of sustainability, the idea that the current generation has responsibility for future generations, originated at least as far back as the 17th century, according to the UN-GSDR 2019, the world is not on track for achieving most of the targets that comprise the SDGs by the target date of 2030. Meanwhile, through the EO4SDG initiative of the GEO, the full potential of RS for SDG monitoring is now being explored at a global scale. As of April 2020, 21 (70\%) of the RS-based SDG indicators already have at least some preliminary statistical data according to the Global SDG Indicators Database, and 10 (33\%) of the RS-based SDG indicators are included in the SDR-ID 2019. These statistics, however, do not necessarily reflect the actual status and availability of raw and processed geospatial data for the RS-based indicators, which remains an important issue. Nevertheless, various initiatives have also been started to address the need for open access data. RS data can also help in the development of potentially relevant complementary indicators or sub-indicators, which will help address one of the current challenges in SDG monitoring, which is how to operationalize the SDG indicators.

Author Contributions: R.C.E. conceptualized this review. He performed the review, prepared all the tables and figures, and wrote the paper. The author has read and agreed to the published version of the manuscript.

Funding: This research was supported by the Japan Society for the Promotion of Science (JSPS), through Grant-in-Aid for Young Scientists (B): 20K13262 (PI: Ronald C. Estoque).

Acknowledgments: This work was also supported by the Climate Change Adaptation Program of the National Institute for Environmental Studies, Japan. The author also acknowledges the four anonymous reviewers whose comments and suggestions helped improve this manuscript.

Conflicts of Interest: The author declares no conflict of interest. 


\section{Appendix A}

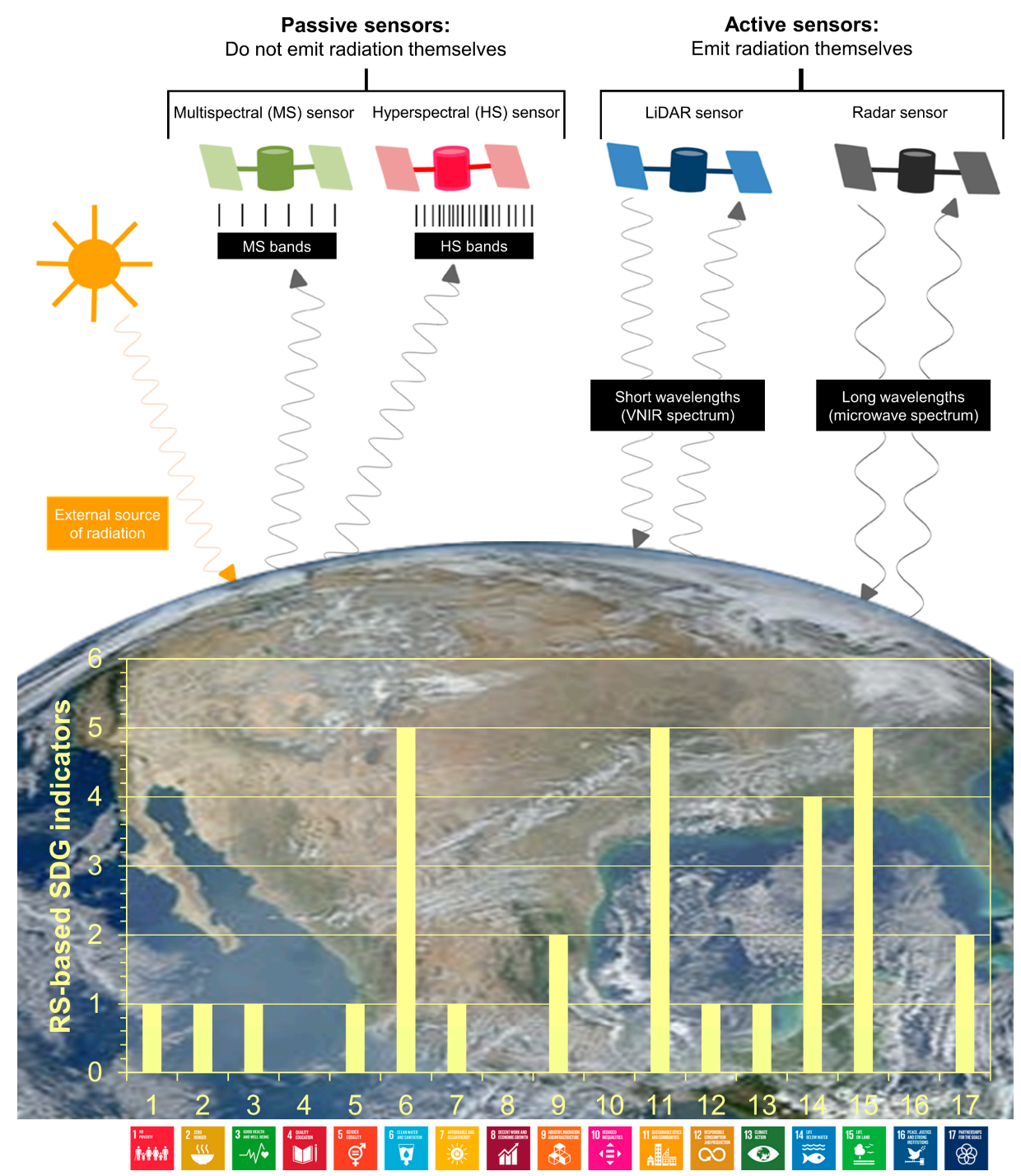

Figure A1. Contributions of RS to SDG monitoring. The diagrams of passive and active remote sensors are from [110]. Passive sensors (e.g., multispectral and hyperspectral sensors) rely on an external source of energy (the sun) and record the radiation reflected by Earth's surface to produce an image, whereas active sensors (e.g., LiDAR and Radar) emit energy in the microwave part of the electromagnetic spectrum and measure the amount of energy reflected back at them [110]. The column graph shows the number of indicators for each of the 17 SDGs to which Earth Observation data can contribute, directly or indirectly [25]. 
Table A1. Widely used multispectral satellite RS data.

\begin{tabular}{|c|c|c|c|c|}
\hline Satellite & $\begin{array}{c}\text { Sensor and } \\
\text { Number of Bands }\end{array}$ & Spatial Resolution & Revisit Interval & Reference \\
\hline Landsat 4/5 TM & MS 6; T 1 & MS \&T: $30 \mathrm{~m}$ & 16 days & [111] \\
\hline $\begin{array}{c}\text { Landsat } 7 \text { ET+/ } \\
8 \text { OLI/TIRS }\end{array}$ & $\begin{array}{c}\text { MS 6/8; } \\
\text { T 1/2; Pan } 1\end{array}$ & $\begin{array}{l}\text { MS \& T: } 30 \mathrm{~m} \\
\text { Pan: } 15 \mathrm{~m}\end{array}$ & 16 days & [111] \\
\hline $\begin{array}{c}\text { SPOT } 1 / 2 / 3 \\
\text { (2 HRVs) }\end{array}$ & MS 3; Pan 1 & $\begin{array}{l}\text { MS: } 20 \mathrm{~m} \\
\text { Pan: } 10 \mathrm{~m}\end{array}$ & 1 to 3 days & [112] \\
\hline $\begin{array}{c}\text { SPOT } 4 \\
\text { (2 HRVIRs) }\end{array}$ & MS 4; Pan 1 & $\begin{array}{l}\text { MS: } 20 \mathrm{~m} \\
\text { Pan: } 10 \mathrm{~m}\end{array}$ & 2 to 3 days & [112] \\
\hline $\begin{array}{l}\text { SPOT } 5 \\
\text { (2 HRGs) }\end{array}$ & MS 4; Pan 2 & $\begin{array}{l}\text { VNIR: } 10 \mathrm{~m} \text {; SWIR: } \\
20 \mathrm{~m} \\
\text { Pan: } 5 \mathrm{~m}(2.5 \mathrm{~m})\end{array}$ & 2 to 3 days & [112] \\
\hline $\begin{array}{c}\text { SPOT 6/7 } \\
\text { (2 NAOMI) }\end{array}$ & MS 4; Pan 1 & $\begin{array}{l}\text { MS: } 8 \mathrm{~m} \\
\text { Pan: } 2 \mathrm{~m}\end{array}$ & Daily & [113] \\
\hline NOAA AVHRR & MS \& T 4-5 & $1.1 \mathrm{~km}$ & $\begin{array}{l}\text { Daily (Vis), } \\
2 \times / \text { day (IR) }\end{array}$ & [114] \\
\hline $\begin{array}{l}\text { OrbView } 2 \\
\text { (SeaWiFS) }\end{array}$ & MS 8 & $1 \mathrm{~km}$ & Daily & [113] \\
\hline IKONOS 2 & MS 4; Pan 1 & $\begin{array}{l}\text { MS: } 3.20 \mathrm{~m} \\
\text { Pan: } 0.82 \mathrm{~m}\end{array}$ & 1 to 3 days & [113] \\
\hline Terra ASTER & MS up to $10 ;$ T 5 & $\begin{array}{l}\text { VNIR: } 15 \mathrm{~m} \text {; SWIR: } \\
30 \mathrm{~m}, \\
\text { T: } 90 \mathrm{~m}\end{array}$ & $\begin{array}{c}\text { All bands: at least } \\
1 \times / 16 \text { days, VNIR: } \\
5 \text { days }\end{array}$ & [115] \\
\hline MODIS Terra/Aqua & MS \& T 36 & $\begin{array}{l}\text { Bands 1-2: } 250 \mathrm{~m} \text {, } \\
\text { Bands 3-7: } 500 \mathrm{~m} \text {, } \\
\text { Bands 8-36: } 1 \mathrm{~km} \\
\text { Ocean: } 1040 \mathrm{~m} \times\end{array}$ & 1 to 2 days & [116] \\
\hline Envisat MERIS & MS 15 & $\begin{array}{l}1200 \mathrm{~m} \text {; Land: } 260 \\
\mathrm{~m} \times 300 \mathrm{~m}\end{array}$ & 3 days & [117] \\
\hline QuickBird & MS 4; Pan 1 & $\begin{array}{l}\text { MS: } 2.40 \mathrm{~m} \\
\text { Pan: } 0.60 \mathrm{~m}\end{array}$ & 1.5 to 2.8 days & [117] \\
\hline GeoEye & MS 4; Pan 1 & $\begin{array}{l}\text { MS: } 1.64 \mathrm{~m} \\
\text { Pan: } 0.41 \mathrm{~m}\end{array}$ & $\leq 3$ days & [113] \\
\hline RapidEye & MS 5 & MS: $\sim 6.5 \mathrm{~m}$ & 1 to 5.5 days & [117] \\
\hline WorldView 2 & MS 8; Pan 1 & $\begin{array}{l}\text { MS: } 1.80 \mathrm{~m}, \\
\text { Pan: } 0.46 \mathrm{~m}\end{array}$ & 1.1 days & [113] \\
\hline Sentinel 2A/2B & MS 13 & $\begin{array}{c}\text { MS: } 10 \mathrm{~m}, 20 \mathrm{~m}, 60 \\
\mathrm{~m}\end{array}$ & $\begin{array}{l}\text { A or B: } 10 \text { days } \\
\text { A \& B: } 5 \text { days }\end{array}$ & [118] \\
\hline
\end{tabular}

Abbreviations: MS, multispectral band; T, thermal band; Pan, panchromatic band; SWIR, short-wave infrared; VNIR, visible and near infrared; Vis, visible; IR, infrared.

Table A2. Widely used radar satellite RS data.

\begin{tabular}{ccccc}
\hline Satellite & Sensor & Spatial Resolution & Revisit Interval & Reference \\
\hline ERS 1/2 & C-band SAR & $30 \mathrm{~m}$ to $50 \mathrm{~km}$ & 35 days & {$[113]$} \\
JERS 1 & L-band SAR & $18 \mathrm{~m}$ & 44 days & {$[113]$} \\
RADARSAT 1/2 & C-band SAR & $10-100 \mathrm{~m} /$ & 24 days & {$[117]$} \\
Envisat ASAR & C-band SAR & $28-100 \mathrm{~m}$ & 35 days & {$[117]$} \\
ALOS PALSAR & L-band SAR & $7-100 \mathrm{~m}$ & 46 days & {$[119]$} \\
TerraSAR-X & X-band SAR & $1-16 \mathrm{~m}$ & 11 days & {$[117]$} \\
TanDEM-X & X-band SAR & $12 \mathrm{~m}$ & 11 days & {$[117]$} \\
ALOS-2 & L-band SAR & $3-100 \mathrm{~m}$ & 14 days & {$[119]$} \\
Sentinel 1/2 SAR & C-band SAR & $5-100 \mathrm{~m}$ & $1 / 2: 6$ days; 1 or 2: & {$[118]$} \\
\hline
\end{tabular}




\section{References}

1. WCED (World Commission on Environment and Development). Our Common Future; Oxford University Press: New York, NY, USA, 1987; ISBN 978-0-19-282080-8.

2. UN General Assembly. Transforming Our World: The 2030 Agenda for Sustainable Development. Resolution Adopted by the General Assembly on 25 September 2015. Available online: https://undocs.org/A/RES/70/1 (accessed on 19 March 2020).

3. UN IAEG-SDGs. Global Indicator Framework for the Sustainable Development Goals and Targets of the 2030 Agenda for Sustainable Development. Available online: https://unstats.un.org/sdgs/indicators/Global\% 20Indicator\%20Framework\%20after\%202020\%20review_Eng.pdf (accessed on 19 March 2020).

4. UN General Assembly. Work of the Statistical Commission Pertaining to the 2030 Agenda for Sustainable Development. Resolution Adopted by the General Assembly on 6 July 2017. Available online: https: //undocs.org/A/RES/71/313 (accessed on 19 March 2020).

5. Barbier, E.B. The concept of sustainable economic development. Environ. Conserv. 1987, 14, 101-110. [CrossRef]

6. Elkington, J. Towards the sustainable corporation: Win-win-win business strategies for sustainable development. Calif. Manage. Rev. 1994, 36, 90-100. [CrossRef]

7. Elkington, J. Cannibals with Forks. The Triple Bottom Line of 21st Century Business; Capston, Publishing Ltd.: Oxford, UK, 1997; ISBN 1-900961-27-X.

8. Estoque, R.C.; Murayama, Y. Social-ecological status index: A preliminary study of its structural composition and application. Ecol. Indic. 2014, 43, 183-194. [CrossRef]

9. Estoque, R.C.; Murayama, Y. A worldwide country-based assessment of social-ecological status (c. 2010) using the social-ecological status index. Ecol. Indic. 2017, 72, 605-614. [CrossRef]

10. Ostrom, E. A diagnostic approach for going beyond panaceas. Proc. Natl. Acad. Sci. USA 2007, 104, 15181-15187. [CrossRef]

11. Ostrom, E. A general framework for analyzing sustainability of social-ecological systems. Science 2009, 325, 419-422. [CrossRef]

12. McGinnis, M.D.; Ostrom, E. Social-ecological system framework: Initial changes and continuing. Ecol. Soc. 2014, 19, 30. [CrossRef]

13. Gallopin, G.C. Environmental and sustainability indicators and the concept of situational indicators. A systems approach. Environ. Model. Assess. 1996, 1, 101-117. [CrossRef]

14. Heink, U.; Kowarik, I. What are indicators? On the definition of indicators in ecology and environmental planning. Ecol. Indic. 2010, 10, 584-593. [CrossRef]

15. Lehtonen, M. Indicators: Tools for informing, monitoring or controlling? In The Tools of Policy Formulation: Actors, Capacities, Venues and Effects. New Horizons in Public Policy; Jordan, A.J., Turnpenny, J.R., Eds.; Edward Elgar: Cheltenham, UK; Northampton, MA, USA, 2015; pp. 76-99. ISBN 9781783477036.

16. Estoque, R.C. GIS-Based Multi-Criteria Decision Analysis in Natural Resource Management; University of Tsukuba: Tsukuba, Japan, 2011.

17. Essex, B.; Koop, S.H.A.; Van Leeuwen, C.J. Proposal for a national blueprint framework to monitor progress on water-related Sustainable Development Goals in Europe. Environ. Manag. 2020, 65, 1-18. [CrossRef]

18. Boulanger, P.-M. Sustainable development indicators: A scientific challenge, a democratic issue. Surv. Perspect. Integrating Environ. Soc. 2008, 1, 45-59. [CrossRef]

19. Maurice, J. Measuring progress towards the SDGs - A new vital science. Lancet 2016, 388, 1455-1458. [CrossRef]

20. UN IAEG-SDGs. Tier Classification for Global SDG Indicators (as of 17 April 2020). Available online: https://unstats.un.org/sdgs/iaeg-sdgs/tier-classification/ (accessed on 2 May 2020).

21. UN Statistics Division. SDG Indicators. Available online: https://unstats.un.org/sdgs/indicators/indicatorslist/ (accessed on 19 March 2020).

22. WGGI (Working Group on Geospatial Information). Terms of Reference; Inter-Agency and Expert Group on SDG Indicators, United Nations: New York, NY, USA, 2019.

23. Anderson, K.; Ryan, B.; Sonntag, W.; Kavvada, A.; Friedl, L. Earth observation in service of the 2030 Agenda for Sustainable Development. Geo-Spat. Inf. Sci. 2017, 20, 77-96. [CrossRef] 
24. Paganini, M.; Petiteville, I.; Ward, S.; Dyke, G.; Steventon, M.; Harry, J.; Kerblat, F. Satellite Earth Observations in Support of the Sustainable Development Goals: The CEOS Earth Observation Handbook; Special 2018 Edition; The Committee on Earth Observation Satellites and the European Space Agency: Paris, France, 2018.

25. GEO. EO4SDG: Earth Observations in Service of the 2030 Agenda for Sustainable Development. Strategic Implementation Plan 2020-2024; Group on Earth Observations: Geneva, Switzerland, 2019.

26. Grant, M.J.; Booth, A. A typology of reviews: An analysis of 14 review types and associated methodologies. Health Inf. Libr. J. 2009, 26, 91-108. [CrossRef]

27. Kidd, C.V. The evolution of sustainability. J. Agric. Environ. Ethics 1992, 5, 1-26. [CrossRef]

28. Grober, U. Deep Roots: A Conceptual History of "Sustainable Development" (Nachhaltigkeit); WZB Discussion Paper, No. P 2007-002; Wissenschaftszentrum Berlin für Sozialforschung (WZB): Berlin, Germany, 2007.

29. Warde, P. The Invention of Sustainability: Nature and Destiny; Cambridge University Press: Cambridge, UK, 2018; ISBN 1-107-15114-7.

30. Purvis, B.; Mao, Y.; Robinson, D. Three pillars of sustainability: In search of conceptual origins. Sustain. Sci. 2019, 14, 681-695. [CrossRef]

31. Du Pisani, J.A. Sustainable development - historical roots of the concept. Environ. Sci. 2006, 3, 83-96. [CrossRef]

32. IUCN. World Conservation Strategy: Living Resource Conservation for Sustainable Development; IUCN-UNEP-WWF: Gland, Switzerland, 1980.

33. Hardin, G. The tragedy of the commons. Science 1968, 162, 1243-1248.

34. Gómez-Pompa, A.; Vázquez-Yanes, C.; Guevara, S. The tropical rain forest: A nonrenewable resource. Science 1972, 177, 762-765. [CrossRef]

35. Westman, W.E. How much are nature's services worth? Science 1977, 197, 960-964. [CrossRef]

36. Ehrlich, P.R.; Ehrlich, A.H. Extinction: The Causes and Consequences of the Disappearance of Species; Random House: New York, NY, USA, 1981; ISBN 0-394-51312-6.

37. de Groot, R.S. Environmental functions as a unifying concept for ecology and economics. Environmentalist 1987, 7, 105-109. [CrossRef]

38. Gómez-Baggethun, E.; de Groot, R.; Lomas, P.L.; Montes, C. The history of ecosystem services in economic theory and practice: From early notions to markets and payment schemes. Ecol. Econ. 2010, 69, 1209-1218. [CrossRef]

39. Diaz, S.; Demissew, S.; Carabias, J.; Joly, C.; Lonsdale, M.; Ash, N.; Larigauderie, A.; Adhikari, J.R.; Arico, S.; Baldi, A.; et al. The IPBES conceptual framework - connecting nature and people. Curr. Opin. Environ. Sustain. 2015, 14, 1-16. [CrossRef]

40. Diaz, S.; Pascual, U.; Stenseke, M.; Martín-López, B.; Watson, R.T.; Molnár, Z.; Hill, R.; Chan, K.M.A.; Baste, I.A.; Brauman, K.A.; et al. Assessing nature's contributions to people. Science 2018, 359, 270-272. [CrossRef]

41. Daily, G.C. (Ed.) Nature's Services. Societal Dependence on Natural Ecosystems; Island Press: Washington, DC, USA, 1997; ISBN 1-55963-476-6.

42. Costanza, R.; D’Arge, R.; de Groot, R.; Farber, S.; Grasso, M.; Hannon, B.; Limburg, K.; Naeem, S.; O’Neill, R.V.; Paruelo, J.; et al. The value of the world's ecosystem services and natural capital. Nature 1997, 387, 253-260. [CrossRef]

43. Estoque, R.C.; Murayama, Y. Measuring sustainability based upon various perspectives: A case study of a hill station in Southeast Asia. AMBIO 2014, 43, 943-956. [CrossRef]

44. Costanza, R. (Ed.) Ecological Economics: The Science and Management of Sustainability; Columbia University Press: New York, NY, USA, 1991; ISBN 0-231-07562-6.

45. Røpke, I. The early history of modern ecological economics. Ecol. Econ. 2004, 50, 293-314. [CrossRef]

46. Rees, W.E. Ecological footprints and appropriated carrying capacity: What urban economics leaves out. Environ. Urban. 1992, 4, 121-130. [CrossRef]

47. Kates, R.W.; Clark, W.C.; Corell, R.; Hall, J.M.; Jaeger, C.C.; Lowe, I.; McCarthy, J.J.; Schellnhuber, H.J.; Bolin, B.; Dickson, N.M.; et al. Sustainability science. Science 2001, 292, 641-642. [CrossRef]

48. NRC USA. Our Common Journey: A Transition Toward Sustainability; Athens Center of Ekistics: New York, NY, USA, 1999. 
49. Rockström, J.; Steffen, W.; Noone, K.; Persson, A.; Chapin, F.S.; Lambin, E.F.; Lenton, T.M.; Scheffer, M.; Folke, C.; Schellnhuber, H.J.; et al. Planetary boundaries: Exploring the safe operating space for humanity. Ecol. Soc. 2009, 14, 32. [CrossRef]

50. Wu, J. Landscape sustainability science: Ecosystem services and human well-being in changing landscapes. Landsc. Ecol. 2013, 28, 999-1023. [CrossRef]

51. UN General Assembly. The Future We Want. Resolution Adopted by the General Assembly on 27 July 2012. Available online: https://sustainabledevelopment.un.org/futurewewant.html (accessed on 19 March 2020).

52. Beckerman, W. "Sustainable development": Is it a useful concept? Environ. Values 2013, 3, 191-209. [CrossRef]

53. Connelly, S. Mapping sustainable development as a contested concept. Local Environ. 2007, 12, $259-278$. [CrossRef]

54. Bell, S.; Morse, S. Sustainability Indicators: Measuring the Immeasurable; Earthscan: London, UK, 2008; ISBN 1-84407-299-1.

55. Pesqueux, Y. Sustainable development: A vague and ambiguous "theory". Soc. Bus. Rev. 2009, 4, $231-245$. [CrossRef]

56. Salas-Zapata, W.A.; Ortiz-Muñoz, S.M. Analysis of meanings of the concept of sustainability. Sustain. Dev. 2019, 27, 153-161. [CrossRef]

57. Daly, H.E. On Wilfred Beckerman's critique of sustainable development. Environ. Values 1995, 4, 49-55. [CrossRef]

58. Salomonson, V.V. Remote sensing, historical perspective. In Encyclopedia of Remote Sensing; Njoku, E.G., Ed.; Springer Science+Business Media: New York, NY, USA, 2014; pp. 684-691.

59. Moore, G.K. What is a picture worth? A history of remote sensing/ Quelle est la valeur d'une image? Un tour d'horizon de télédétection. Hydrol. Sci. Bull. 1979, 24, 177-485. [CrossRef]

60. Andries, A.; Morse, S.; Murphy, R.J.; Lynch, J.; Woolliams, E.R. Seeing sustainability from space: Using Earth observation data to populate the UN Sustainable Development Goal indicators. Sustainability 2019, 11, 5062. [CrossRef]

61. Weng, Q. (Ed.) Remote Sensing for Sustainability; CRS Press: Boca Raton, FL, USA, 2016; ISBN 1-4987-0071-3.

62. Rao, U.R. Remote sensing for sustainable development. J. Indian Soc. Remote Sens. 1991, 19, $217-235$. [CrossRef]

63. Hansen, M.C.; Potapov, P.V.; Moore, R.; Hancher, M.; Turubanova, S.A.; Tyukavina, A.; Thau, D.; Stehman, S.V.; Goetz, S.J.; Loveland, T.R.; et al. High-resolution global maps of 21st-century forest cover change. Science 2013, 342, 850-853. [CrossRef]

64. de Araujo Barbosa, C.C.; Atkinson, P.M.; Dearing, J.A. Remote sensing of ecosystem services: A systematic review. Ecol. Indic. 2015, 52, 430-443. [CrossRef]

65. Estoque, R.C.; Ooba, M.; Avitabile, V.; Hijioka, Y.; DasGupta, R.; Togawa, T.; Murayama, Y. The future of Southeast Asia's forests. Nat. Commun. 2019, 10, 1829. [CrossRef] [PubMed]

66. Song, X.P.; Hansen, M.C.; Stehman, S.V.; Potapov, P.V.; Tyukavina, A.; Vermote, E.F.; Townshend, J.R. Global land change from 1982 to 2016. Nature 2018, 560, 639-643. [CrossRef] [PubMed]

67. Chen, C.; Park, T.; Wang, X.; Piao, S.; Xu, B.; Chaturvedi, R.K.; Fuchs, R.; Brovkin, V.; Ciais, P.; Fensholt, R.; et al. China and India lead in greening of the world through land-use management. Nat. Sustain. 2019, 2, 122-129. [CrossRef]

68. Kerr, J.T.; Ostrovsky, M. From space to species: Ecological applications for remote sensing. Trends Ecol. Evol. 2003, 18, 299-305. [CrossRef]

69. Wang, K.; Franklin, S.E.; Guo, X.; Cattet, M. Remote sensing of ecology, biodiversity and conservation: A review from the perspective of remote sensing specialists. Sensors 2010, 10, 9647-9667. [CrossRef] [PubMed]

70. Kwok, R. Ecology's remote-sensing evolution. Nature 2018, 556, 137-138. [CrossRef]

71. Yu, H.; Liu, X.; Kong, B.; Li, R.; Wang, G. Landscape ecology development supported by geospatial technologies: A review. Ecol. Inform. 2019, 51, 185-192. [CrossRef]

72. Schmugge, T.J.; Kustas, W.P.; Ritchie, J.C.; Jackson, T.J.; Rango, A. Remote sensing in hydrology. Adv. Water Resour. 2002, 25, 1367-1385. [CrossRef]

73. Crow, W.T.; Chen, F.; Reichle, R.H.; Liu, Q. L band microwave remote sensing and land data assimilation improve the representation of prestorm soil moisture conditions for hydrologic forecasting. Geophys. Res. Lett. 2017, 44, 5495-5503. [CrossRef] 
74. Thies, B.; Bendix, J. Satellite based remote sensing of weather and climate: Recent achievements and future perspectives. Meteorol. Appl. 2011, 18, 262-295. [CrossRef]

75. Yang, J.; Gong, P.; Fu, R.; Zhang, M.; Chen, J.; Liang, S.; Xu, B.; Shi, J.; Dickinson, R. The role of satellite remote sensing in climate change studies. Nat. Clim. Change 2013, 3, 875-883. [CrossRef]

76. Voogt, J.A.; Oke, T.R. Thermal remote sensing of urban climates. Remote Sens. Environ. 2003, 86, 370-384. [CrossRef]

77. Weng, Q.; Lu, D.; Schubring, J. Estimation of land surface temperature-vegetation abundance relationship for urban heat island studies. Remote Sens. Environ. 2004, 89, 467-483. [CrossRef]

78. Weng, Q. Thermal infrared remote sensing for urban climate and environmental studies: Methods, applications, and trends. ISPRS J. Photogramm. Remote Sens. 2009, 64, 335-344. [CrossRef]

79. Estoque, R.C.; Murayama, Y. Monitoring surface urban heat island formation in a tropical mountain city using Landsat data (1987-2015). ISPRS J. Photogramm. Remote Sens. 2017, 133, 18-29. [CrossRef]

80. Estoque, R.C.; Murayama, Y.; Myint, S.W. Effects of landscape composition and pattern on land surface temperature: An urban heat island study in the megacities of Southeast Asia. Sci. Total Environ. 2017, 577, 349-359. [CrossRef]

81. Blaschke, T. Object based image analysis for remote sensing. ISPRS J. Photogramm. Remote Sens. 2010, 65, 2-16. [CrossRef]

82. Myint, S.W.; Gober, P.; Brazel, A.; Grossman-Clarke, S.; Weng, Q. Per-pixel vs. object-based classification of urban land cover extraction using high spatial resolution imagery. Remote Sens. Environ. 2011, 115, 1145-1161. [CrossRef]

83. Weng, Q. Remote sensing of impervious surfaces in the urban areas: Requirements, methods, and trends. Remote Sens. Environ. 2012, 117, 34-49. [CrossRef]

84. Blaschke, T.; Hay, G.J.; Kelly, M.; Lang, S.; Hofmann, P.; Addink, E.; Queiroz, F.; van der Meer, F.; van der Werff, H.; van Coillie, F.; et al. Geographic Object-Based Image Analysis-Towards a new paradigm. ISPRS J. Photogramm. Remote Sens. 2014, 87, 180-191. [CrossRef]

85. Estoque, R.C.; Murayama, Y. Classification and change detection of built-up lands from Landsat-7 ETM+ and Landsat- 8 OLI/TIRS imageries: A comparative assessment of various spectral indices. Ecol. Indic. 2015, 56, 205-217. [CrossRef]

86. Gupta, P.; Christopher, S.A.; Wang, J.; Gehrig, R.; Lee, Y.; Kumar, N. Satellite remote sensing of particulate matter and air quality assessment over global cities. Atmos. Environ. 2006, 40, 5880-5892. [CrossRef]

87. Martin, R.V. Satellite remote sensing of surface air quality. Atmos. Environ. 2008, 42, 7823-7843. [CrossRef]

88. Beck, L.R.; Lobitz, B.M.; Wood, B.L. Remote sensing and human health: New sensors and new opportunities. Emerg. Infect. Dis. 2000, 6, 217-227. [CrossRef] [PubMed]

89. Maxwell, S.K.; Meliker, J.R.; Goovaerts, P. Use of land surface remotely sensed satellite and airborne data for environmental exposure assessment in cancer research. J. Expo. Sci. Environ. Epidemiol. 2010, 20, 176-185. [CrossRef] [PubMed]

90. Seltenrich, N. Remote-sensing applications for environmental health. Environ. Health Perspect. 2014, 122, A268-A275. [CrossRef] [PubMed]

91. Estoque, R.C.; Ooba, M.; Seposo, X.T.; Togawa, T.; Hijioka, Y.; Takahashi, K.; Nakamura, S. Heat health risk assessment in Philippine cities using remotely sensed data and social-ecological indicators. Nat. Commun. 2020, 11, 1581. [CrossRef] [PubMed]

92. Joyce, K.E.; Belliss, S.E.; Samsonov, S.V.; McNeill, S.J.; Glassey, P.J. A review of the status of satellite remote sensing and image processing techniques for mapping natural hazards and disasters. Prog. Phys. Geogr. Earth Environ. 2009, 33, 183-207. [CrossRef]

93. Kaku, K. Satellite remote sensing for disaster management support: A holistic and staged approach based on case studies in Sentinel Asia. Int. J. Disaster Risk Reduct. 2019, 33, 417-432. [CrossRef]

94. de Sherbinin, A.; Levy, M.A.; Zell, E.; Weber, S.; Jaiteh, M. Using satellite data to develop environmental indicators. Environ. Res. Lett. 2014, 9, 084013. [CrossRef]

95. Giuliani, G.; Mazzetti, P.; Santoro, M.; Nativi, S.; Van Bemmelen, J.; Colangeli, G.; Lehmann, A. Knowledge generation using satellite earth observations to support sustainable development goals (SDG): A use case on Land degradation. Int. J. Appl. Earth Obs. Geoinf. 2020, 88, 102068. [CrossRef]

96. Adams, B.B.; Judd, K. Global Indicator Framework for SDGs: Value Added or Time to Start Over? Global Policy Forum: New York, NY, USA, 2019. 
97. Sachs, J.; Schmidt-Traub, G.; Kroll, C.; Lafortune, G.; Fuller, G. Sustainable Development Report 2019. Transformations to Achieve the Sustainable Development Goals: Includes the SDG Index and Dashboards; Bertelsmann Stiftung and Sustainable Development Solutions Network (SDSN): New York, NY, USA, 2019.

98. Independent Group of Scientists appointed by the Secretary-General. Global Sustainable Development Report 2019: The Future is Now-Science for Achieving Sustainable Development; United Nations: New York, NY, USA, 2019.

99. FAO. Global Forest Resources Assessment 2015: How are the World's Forests Changing? second ed.; UN Food and Agriculture Organization: Rome, Italy, 2015.

100. Prince, S.D. Challenges for remote sensing of the Sustainable Development Goal SDG 15.3.1 productivity indicator. Remote Sens. Environ. 2019, 234, 111428. [CrossRef]

101. Mulligan, M.; van Soesbergen, A.; Hole, D.G.; Brooks, T.M.; Burke, S.; Hutton, J. Mapping nature's contribution to SDG 6 and implications for other SDGs at policy relevant scales. Remote Sens. Environ. 2020, 239, 111671. [CrossRef]

102. Watmough, G.R.; Marcinko, C.L.J.; Sullivan, C.; Tschirhart, K.; Mutuo, P.K.; Palm, C.A.; Svenning, J.C. Socioecologically informed use of remote sensing data to predict rural household poverty. Proc. Natl. Acad. Sci. USA 2019, 116, 1213-1218. [CrossRef] [PubMed]

103. Boyd, D.S.; Jackson, B.; Wardlaw, J.; Foody, G.M.; Marsh, S.; Bales, K. Slavery from Space: Demonstrating the role for satellite remote sensing to inform evidence-based action related to UN SDG number 8. ISPRS J. Photogramm. Remote Sens. 2018, 142, 380-388. [CrossRef]

104. Macfeely, S. The big (data) bang: Opportunities and challenges for compiling SDG indicators. Glob. Policy 2019, 10, 121-133. [CrossRef]

105. Pradhan, P.; Costa, L.; Rybski, D.; Lucht, W.; Kropp, J.P. A systematic study of Sustainable Development Goal (SDG) interactions. Earths Future 2017, 5, 1169-1179. [CrossRef]

106. Singh, G.G.; Cisneros-Montemayor, A.M.; Swartz, W.; Cheung, W.; Guy, J.A.; Kenny, T.A.; McOwen, C.J.; Asch, R.; Geffert, J.L.; Wabnitz, C.C.C.; et al. A rapid assessment of co-benefits and trade-offs among Sustainable Development Goals. Mar. Policy 2018, 93, 223-231. [CrossRef]

107. Kroll, C.; Warchold, A.; Pradhan, P. Sustainable Development Goals (SDGs): Are we successful in turning trade-offs into synergies? Palgrave Commun. 2019, 5, 140. [CrossRef]

108. Biggeri, M.; Clark, D.A.; Ferrannini, A.; Mauro, V. Tracking the SDGs in an 'integrated' manner: A proposal for a new index to capture synergies and trade-offs between and within goals. World Dev. 2019, 122, 628-647. [CrossRef]

109. Xu, Z.; Chau, S.N.; Chen, X.; Zhang, J.; Li, Y.; Dietz, T.; Wang, J.; Winkler, J.A.; Fan, F.; Huang, B.; et al. Assessing progress towards sustainable development over space and time. Nature 2020,577,74-78. [CrossRef]

110. Pettorelli, N.; Schulte toBühne, H.; Shapiro, A.C.; Glover-Kapfer, P. Satellite Remote Sensing for Conservation; WWF Conservation Technology Series 1(4); World Wide Fund for Nature: Gland, Switzerland, 2018.

111. USGS. What Are the Band Designations for the Landsat Satellites? Available online: https://www.usgs.gov/faqs/what-are-band-designations-landsat-satellites?qt-news_science_products=0\# qt-news_science_products (accessed on 19 March 2020).

112. Airbus Intelligence. SPOT Image: Spot Satellite Technical Data. Available online: https://www.intelligenceairbusds.com/files/pmedia/public/r329_9_spotsatellitetechnicaldata_en_sept2010.pdf (accessed on 19 March 2020).

113. EO Portal Directory. Satellite Missions Database. Available online: https://directory.eoportal.org/web/ eoportal/satellite-missions (accessed on 19 March 2020).

114. NOAA. AVHRR. Available online: https://www.avl.class.noaa.gov/release/data_available/avhrr/index.htm (accessed on 19 March 2020).

115. USGS. AST_L1T Product User's Guide. Available online: https://lpdaac.usgs.gov/documents/71/AST_L1T_ User_Guide_V3.pdf (accessed on 19 March 2020).

116. NASA MODIS. Specifications. Available online: https://modis.gsfc.nasa.gov/about/specifications.php (accessed on 19 March 2020).

117. ESA (European Space Agency) Earth Online. Earth Observation Information Discovery Platform. Available online: https://earth.esa.int/eogateway (accessed on 19 March 2020). 
118. Sentinel Online. User Guides Introduction. Available online: https://sentinel.esa.int/web/sentinel/user-guides (accessed on 19 March 2020).

119. JAXA (Japan Aerospace Exploration Agency) Earth Observation Research Center. Available online: https: //www.eorc.jaxa.jp/en/index.html (accessed on 19 March 2020). 